\title{
稻茬小麦氮高效品种产量构成和群体质量特征
}

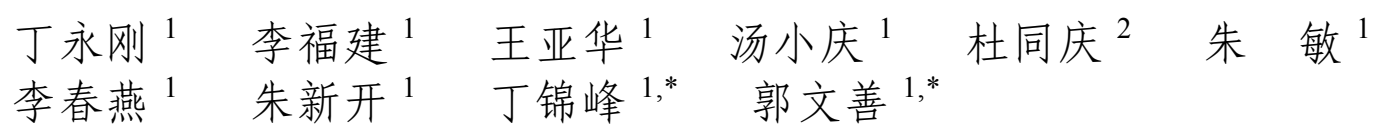

${ }^{1}$ 江苏省作物遗传生理重点实验室 / 江苏省作物栽培生理重点实验室 / 江苏省粮食作物现代产业技术协同创新中心 / 扬州大学小麦 研究中心, 江苏扬州 $225009 ;{ }^{2}$ 睢宁县植物保护技术指导站, 江苏徐州 221200

摘 要: 在稻麦两熟条件下, 将 2016-2017 和 2017-2018 年江苏扬州参试的 24 个和江苏睢宁参试的 23 个小麦品 种按氮肥表观利用率(NUR)划分为高效(NUR $\geq 50 \%$ )、中效(NUR 40\% 50\%)和低效(NUR $\leq 40 \%$ )品种类型, 比较其产 量、产量构成因素和群体质量指标的差异, 为稻茬小麦品种选用和大面积高产高效生产提供参考。结果表明, 两年度 在扬州均表现出高效的品种为扬麦 25 和宁麦 21 , 在睢宁为淮麦 35 。扬州和㫿宁氮高效品种产量分别高于 $6500 \mathrm{~kg}$ $\mathrm{hm}^{-2}$ 和 $7000 \mathrm{~kg} \mathrm{hm}^{-2}$, 均显著高于其他类型。与氮中效和氮低效品种相比, 氮高效品种具有较高的穗数, 穗粒数和千 粒重品种类型间差异不显著。不同品种间产量和穗数与 NUR 均呈线性正相关。氮高效品种具有较高的孕穗期和开花 期茎竪数, 分藍成穗率, 乳熟期叶面积指数, 孕穗期、开花期和成熟期干物质积累量, 花后干物质积累量和成熟期各 营养器官干物质积累量。不同氮效率品种类型间花前干物质转运量和收获指数差异不显著。相关性分析表明, 两地 不同品种类型间孕穗期和开花期茎藮数、乳熟期 LAI、主要生育时期干物质积累量、花后和成熟期各营养器官干物 质积累量均与氮肥表观利用率呈极显著线性正相关。表明稻茬小麦氮高效品种生育早期表现出较强分藮能力, 且生 育后期具有较高叶面积指数和光合生产能力, 可用于灌浆的花后同化物质较多。本研究初步提出成熟期干物质积累 量 16,000 20,000 $\mathrm{kg} \mathrm{hm}^{-2}$ 和花后干物质积量 4100 6700 $\mathrm{kg} \mathrm{hm}^{-2}$ 可作为稻茬小麦高产高效品种的篮选指标。

关键词: 稻茬小麦; 品种; 氮肥表观利用率; 产量构成; 群体质量

\section{Characteristics of yield components and population quality in high-nitrogen- utilization wheat cultivars}

DING Yong-Gang ${ }^{1}$, LI Fu-Jian ${ }^{1}$, WANG Ya-Hua ${ }^{1}$, TANG Xiao-Qing ${ }^{1}$, DU Tong-Qing ${ }^{2}$, ZHU Min ${ }^{1}$, LI Chun-Yan ${ }^{1}$, ZHU Xin-Kai ${ }^{1}$, DING Jin-Feng ${ }^{1, *}$, and GUO Wen-Shan ${ }^{1, *}$

${ }^{1}$ Jiangsu Key Laboratory of Crop Genetics and Physiology / Jiangsu Key Laboratory of Crop Cultivation and Physiology / Jiangsu Co-innovation Center for Modern Production Technology of Grain Crops / Wheat Research Institute, Yangzhou University, Yangzhou 225009, Jiangsu, China; ${ }^{2}$ Suining Plant Protection Management Station, Xuzhou 221200, Jiangsu, China

\begin{abstract}
In the rice-wheat rotation system, 24 and 23 wheat cultivars were separately planted in Yangzhou and Suining of Jiangsu province in 2016-2017 and 2017-2018. According to nitrogen utilization rate (NUR), these cultivars were clustered into three groups, i.e., NUR-H (NUR $\geq 50 \%$ ), NUR-M (NUR 40\%-50\%), and NUR-L (NUR $\leq 40 \%$ ), to identify the differences in grain yield, yield components, and population quality, which would provide a reference for cultivar selection for high-yield and high-efficiency in wheat production. Yangmai 25 and Ningmai 21 in Yangzhou and Huaimai 35 in Suining showed NUR-H phe-
\end{abstract}

本研究由国家重点研发计划项目(2016YFD0300405), 国家自然科学基金项目(31771711), 江苏省现代农业(小麦)产业技术体系建设项 目, 江苏高校优势学科建设工程项目, 江苏高校品牌专业建设工程项目(PPZY2015A060)和扬州大学科技创新团队项目资助。

This study was supported by the National Key Research and Development Program of China (2016YFD0300405), the National Natural Science Foundation of China (31771711), the Technology System of Modern Agriculture Industry (Wheat) in Jiangsu Province, the Priority Academic Program Development of Jiangsu Higher Education Institutions, the Top-notch Academic Programs Project of Jiangsu Higher Education Institutions (PPZY2015A060), and the Science and Technology Innovation Team of Yangzhou University.

*通信作者(Corresponding authors): 丁锦峰, E-mail: jfdin@yzu.edu.cn; 郭文善, E-mail: wheat@yzu.edu.cn

第一作者联系方式: E-mail: 2659307381@qq.com

Received (收稿日期): 2019-06-24; Accepted (接受日期): 2019-12-26; Published online (网络出版日期): 2020-01-14.

URL: http://kns.cnki.net/kcms/detail/11.1809.S.20200113.1718.006.html 
notypes in consecutive two years. Grain yield of the NUR-H cultivars was more than $6500 \mathrm{~kg} \mathrm{hm}^{-2}$ in Yangzhou and $7000 \mathrm{~kg} \mathrm{hm}^{-2}$ in Suining, which were significantly higher than those of NUR-M and NUR-L groups. NUR-H group had more spikes, and it grains per spike and 1000-grain weight were not significantly different from those of the other groups. Grain yield and spikes number were significantly positively correlated with NUR among different cultivars. More stem and tiller number, higher percentage of fertile tillers and higher leaf area index (LAI) at the milk-ripening stage were shown in the NUR-H group. A higher dry matter accumulation at stages of booting, anthesis, and maturity, after anthesis, and in the vegetative organs at maturity were found in the NUR-H group. However, there were no differences in dry matter remobilization and harvest index among different cultivars. Number of stems and tillers at booting and anthesis, LAI at the milk-ripe stage, and dry matter accumulation at each stage after anthesis, and in the vegetative organs at maturity were significantly positively correlated with NUR in the all cultivar in two sites. A vigorous tillering capacity at the early growing phase and a higher LAI and photosynthetic production at the late growth stages could be observed in NUR-H cultivars, resulting in more photosynthate for grain-filling. Furthermore, the critical parameters of cultivar screening for high-yield and high-efficiency in wheat following rice were proposed, that is $16,000-20,000$ $\mathrm{kg} \mathrm{hm}^{-2}$ dry matter accumulation at maturity and $4100-6700 \mathrm{~kg} \mathrm{hm}^{-2}$ dry matter accumulation after anthesis.

Keywords: wheat following rice; varieties; nitrogen utilization rate; yield components; population quality characteristics

小麦作为我国主要的粮食作物，其高产稳产关 系着国家的粮食安全 ${ }^{[1]}$ 。施用氮肥对小麦产量的提 高起着重要作用, 适量施用氮肥有利于促进小麦生 长发育, 提高产量 ${ }^{[2]}$, 但过量施用不仅会导致氮肥 利用率降低, 还会造成资源浪费, 甚至环境污染 ${ }^{[3]}$ 。 前人研究表明, 不同小麦品种间氮素吸收和利用存 在明显差异 ${ }^{[4-5]}$, 通过选用和推广高效利用氮素的品 种已成为控制氮肥施用量、稳定产量和提高氮肥利 用效率的重要途径 ${ }^{[6]}$ 。氮肥表观利用率 (nitrogen utilization rate, NUR)作为反映氮肥利用率的关键指 标之一, 前人对不同氮肥表观利用率小麦品种和群 体的差异机制已开展了较多研究 ${ }^{[7]}$ 。李淑文等 ${ }^{[7]}$ 研究 认为旱茬条件下, 氮高效品种的产量、穗数和群体 干物质积累量均高于氮中效和氮低效品种。张洋等 ${ }^{[8]}$ 研究认为旱茬小麦氮高效品种具有较高的穗粒数和 千粒重。韩胜芳等 ${ }^{[9]}$ 研究认为在低氮条件下, 旱茬小 麦氮高效品种的茎叶干物质积累量高于氮中效和氮 低效品种。丁锦峰等 ${ }^{[10]}$ 认为稻茬小麦氮高效群体花 后和总的干物质积累量高于氮中效和氮低效群体, 熊淑萍等 ${ }^{[5]}$ 分析了稻茬小麦氮高效品种(系)的根系 特征, 而对稻茬小麦氮高效品种产量构成和群体质 量特征报道较少。本研究在稻茬条件下, 研究不同 氮效率品种类型间产量及其构成、主要生育时期茎 蒒数和叶面积指数、干物质积累、转运和分配的差 异及其与氮肥表观利用率的关系, 明确稻茬小麦氮 高效品种的产量构成和群体质量特征, 以期为稻茬 小麦品种选用及其大面积高产高效生产提供参考。

\section{1 材料与方法}

\section{1 试验设计}

1.1 .1 试验一

于 2016-2018 年度在扬州大学
江苏省作物遗传生理重点实验室试验场农场(扬州) 进行。试验田前茬为水稻, 土壤为轻壤土。 2016-2017 年度小麦播种前 0 20 cm 土壤含碱解氮 $77.67 \mathrm{mg} \mathrm{kg}^{-1}$ 、速效磷 $76.47 \mathrm{mg} \mathrm{kg}$ 、速效钾 $114.5 \mathrm{mg} \mathrm{kg}^{-1}$ 和有机质 $21.82 \mathrm{~g} \mathrm{~kg}^{-1} ; 2017$-2018 年 度小麦播种前 $0 \sim 20 \mathrm{~cm}$ 土壤含碱解氮 $77.25 \mathrm{mg} \mathrm{kg}^{-1}$ 、 速效磷 $98.98 \mathrm{mg} \mathrm{kg}^{-1}$ 、速效钾 $58.26 \mathrm{mg} \mathrm{kg}^{-1}$ 和有机 质 $18.41 \mathrm{~g} \mathrm{~kg}^{-1}$ 。试验年度气候见图 1。采用单因素 随机区组设计, 两年度 24 个供试品种详见表 1 。分 别于 2016 年 11 月 17 日和 2017 年 10 月 30 日播种, 两年基本苗均为 $225 \times 10^{4}$ 株 $\mathrm{hm}^{-2}$, 行距 $25 \mathrm{~cm}$, 于三 叶期定苗。施氮量 $(\mathrm{N})$ 为 $240 \mathrm{~kg} \mathrm{hm}^{-2}$, 设置基肥: 壮 莉肥：拔节肥：孕穗肥为 $5: 1: 2: 2$, 基肥于播种 前施用, 壮藍肥于五叶期施用, 拔节肥于倒三叶期 施用, 孕穗肥于剑叶露尖施用。磷肥 $\left(\mathrm{P}_{2} \mathrm{O}_{5}\right)$ 、钾 $\left(\mathrm{K}_{2} \mathrm{O}\right)$ 肥施用量均为 $144 \mathrm{~kg} \mathrm{hm}^{-2}$, 全部基施。小区面积 $18 \mathrm{~m}^{2}$, 同时设不施氮对照。重复 3 次, 其余栽培措 施同当地高产田。

1.1.2 试验二 于 2016-2018 年度在江苏省睢 宁县现代农业示范基地(睢宁)进行。试验田前茬为水 稻, 土壤为沙壤土。2016-2017 年度小麦播种前 0 20 cm 土壤含碱解氮 $71.09 \mathrm{mg} \mathrm{kg}{ }^{-1}$ 、速效磷 $16.03 \mathrm{mg} \mathrm{kg}^{-1}$ 、速效钾 $103 \mathrm{mg} \mathrm{kg}^{-1}$ 和有机质 $15.29 \mathrm{~g} \mathrm{~kg}^{-1} ; 2017$-2018 年度小麦播种前 $0 \sim 20 \mathrm{~cm}$ 土壤含碱解氮 $66.07 \mathrm{mg} \mathrm{kg}^{-1}$ 、速效磷 $44.31 \mathrm{mg} \mathrm{kg}^{-1}$ 、 速效钾 $69.65 \mathrm{mg} \mathrm{kg}^{-1}$ 和有机质 $15.17 \mathrm{~g} \mathrm{~kg}^{-1}$ 。试验年 度气候见图 1。采用单因素随机区组设计。两年度 23 个供试品种详见表 1 。分别于 2016 年 11 月 18 日 和 2017 年 11 月 1 日播种。2016-2017 年基本苗为 $270 \times 10^{4}$ 株 $\mathrm{hm}^{-2}, 2017-2018$ 年度基本苗为 $225 \times 10^{4}$ 株 $\mathrm{hm}^{-2}$, 行距 $25 \mathrm{~cm}$, 于三叶期定苗。施氮量 $(\mathrm{N})$ 为 


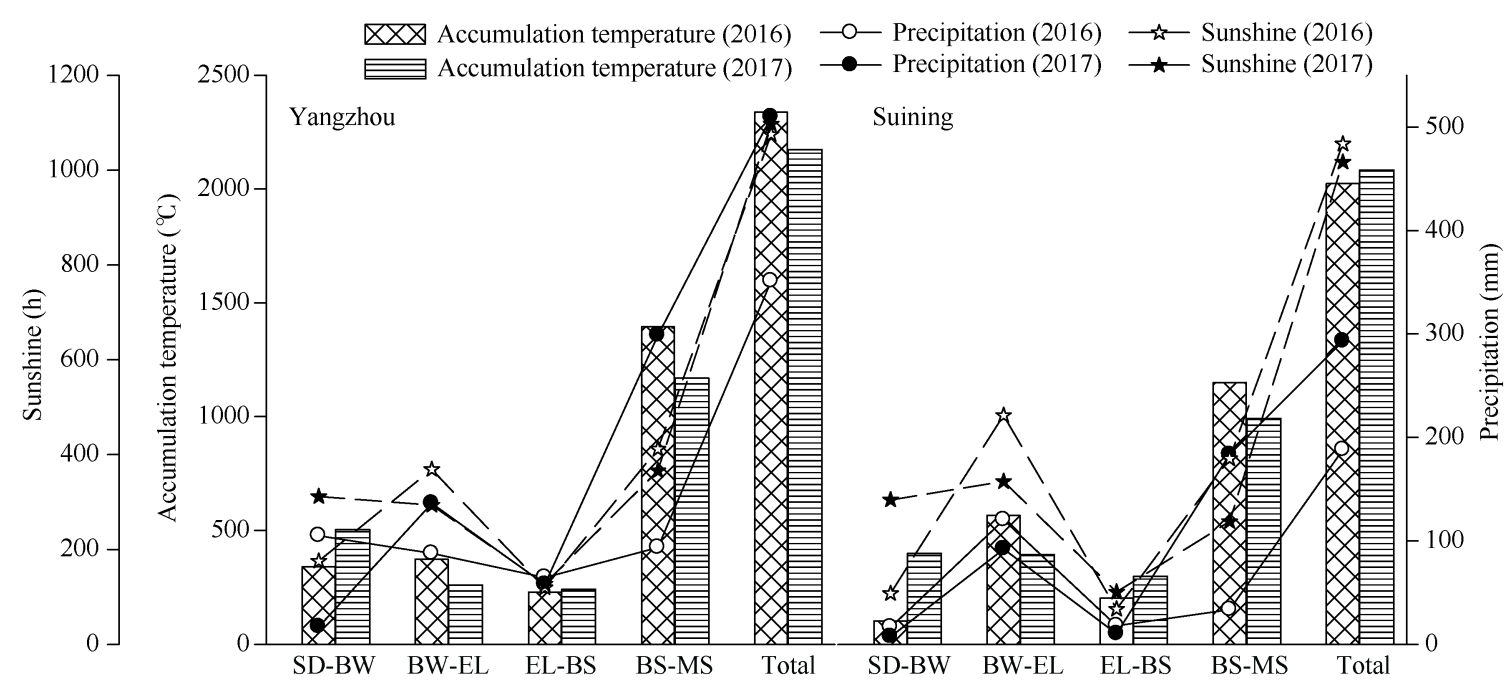

图 1 小麦不同生育阶段的积温、日照和降雨量

Fig. 1 Accumulated temperature, precipitation, and sunshine during different growth phases

$\mathrm{SD}$ ：播种; BW：越冬始期; EL：拔节期; BS：孕穗期; MS：成熟期。

SD: seeding; BW: beginning of winter; EL: elongation; BT: booting stage; MS: maturity stage.

$240 \mathrm{~kg} \mathrm{hm}^{-2}$, 设置基肥：壮菜肥：拔节肥：孕穗肥 为 5: $1: 2: 2$ 。磷肥 $\left(\mathrm{P}_{2} \mathrm{O}_{5}\right)$ 、钾肥 $\left(\mathrm{K}_{2} \mathrm{O}\right)$ 施用量均为 $144 \mathrm{~kg} \mathrm{hm}^{-2}$, 肥料施用方法同试验一。小区面积 $18 \mathrm{~m}^{2}$, 同时设不施氮对照。重复 3 次, 其他栽培措 施同当地高产田。

\section{2 测定项目与方法}

\subsection{1 茎藥数、叶面积指数( $\mathrm{LAI})$ 和干物质积累量}

于拔节期、孕穗期、开花期、成熟期选取长势均 匀的 3 个 $1 \mathrm{~m}$ 行段调查田间茎蓝数。于孕穗期、开花 期、乳熟期，从各小区取样 20 株，采用台式叶面积仪 (LI-3100C, 美国)测定绿叶叶面积, LAI = 样品叶面 积 $\left(\mathrm{cm}^{2}\right)$ 株数 $\times$ 基本苗(株 $\left.\mathrm{m}^{-2}\right)$ 。于孕穗期、开花期、 成熟期, 从各小区取样 20 株, 按器官分开, $105^{\circ} \mathrm{C}$ 杀 青 $1 \mathrm{~h}, 80^{\circ} \mathrm{C}$ 烘干至恒重, 测定干物质积累量。

\subsection{2 氮素含量和积累量 将开花期和成熟期植} 株样品烘干后磨碎, 称取 $0.25 \mathrm{~g}$, 用 $\mathrm{H}_{2} \mathrm{SO}_{4}-\mathrm{H}_{2} \mathrm{O}_{2}$ 消 解-靛酚蓝比色法 ${ }^{[11]}$ 测定样品含氮率, 计算植株氮素 积累量。

\subsection{3 产量及产量结构 于乳熟期连续取 50 个} 麦穗, 调查穗粒数。于成熟期划定各小区 3 个 $1 \mathrm{~m}^{2}$ 区域, 调查穗数。人工收割脱粒, 自然晒干后称重, 并数 1000 粒测千粒重。测定籽粒含水率, 折算为 $13 \%$ 含水率的每公顷籽粒产量和千粒重。

\section{3 计算方法与统计方法}

氮肥表观利用率(nitrogen utilization rate, NUR) $(\%)=($ 施氮处理植株氮素积累量 - 不施氮处理植 株氮素积累量 $) /$ 施氮量 $\times 100 \%$ 。
采用 SPSS19.0 软件统计分析所有数据, LSD 法 检验差异显著性。采用线性方程 $y=a x+b$ 拟合不同 品种间穗数、每穗粒数、千粒重和主要生育时期茎 菜数与氮肥表观利用率的关系, 并用 SigmaPlot 10.0 作图。

\section{2 结果与分析}

\section{1 参试品种氮肥表观利用率和籽粒产量的差异}

由表 1 可知, 根据两地参试品种的氮肥表观利 用率将品种划分为氮高效(NUR $\geq 50 \%$ )、氮中效 (NUR 40\% 50\%)和氮低效(NUR $\leq 40 \%$ ) 3 个品种 类型。由于年际间天气变化和栽培措施的变化, 两 地参试品种的氮肥表观利用率年度间表现并不一致， 其中扬州参试的氮高效品种为扬麦 25 和宁麦 21 , 氮 中效品种为扬麦 13, 氮低效品种为扬辐麦 2054、生 选 6 号、宁麦 23、宁麦 13 和苏麦 10 号。睢宁参试 的氮高效品种为淮麦 35 , 氮中效品种为保麦 5 号、 淮麦 33 和山农 20 , 氮低效品种为保麦 2 号和鄂麦 580 ，年度间品种的氮肥表观利用率表现一致。

由表 2 可知, 不同品种间氮肥表观利用率和籽 粒产量均存在显著差异。2017 年度, 扬州参试的小 麦品种籽粒产量变幅为 $4158 \sim 7949 \mathrm{~kg} \mathrm{hm}^{-2}$, 平均为 $6470 \mathrm{~kg} \mathrm{hm}^{-2}$; 氮肥表观利用率变幅为 $31.4 \% \sim 55.8 \%$, 平均为 $43.55 \%$ 。睢宁参试的小麦品种籽粒产量变幅 为 $6186 \sim 9370 \mathrm{~kg} \mathrm{hm}^{-2}$, 平均为 $8252 \mathrm{~kg} \mathrm{hm}^{-2}$; 氮肥表 观利用率变幅为 $33.5 \% \sim 53.5 \%$, 平均为 $44.44 \%$ 。 2018 年度, 扬州参试的小麦品种籽粒产量变幅为 


\section{表 1 参试的各类型小麦品种}

Table 1 Different types of wheat varieties in the test

\begin{tabular}{|c|c|c|c|c|c|}
\hline $\begin{array}{l}\text { 年份 } \\
\text { Year }\end{array}$ & $\begin{array}{l}\text { 地点 } \\
\text { Site }\end{array}$ & $\begin{array}{l}\text { 品种类型 } \\
\text { Variety } \\
\text { type }\end{array}$ & $\begin{array}{l}\text { 氮肥表观 } \\
\text { 利用率 } \\
\text { NUR } \\
\text { range (\%) }\end{array}$ & $\begin{array}{l}\text { 统计数 } \\
\text { Number }\end{array}$ & $\begin{array}{c}\text { 品种 } \\
\text { Cultivars }\end{array}$ \\
\hline \multirow[t]{6}{*}{$2016-2017$} & $\begin{array}{l}\text { 扬州 } \\
\text { Yangzhou }\end{array}$ & $\begin{array}{l}\text { 氮高效 } \\
\text { NUR-H }\end{array}$ & $\geq 50$ & 8 & 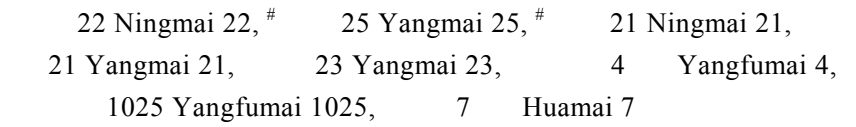 \\
\hline & & $\begin{array}{l}\text { 氮中效 } \\
\text { NUR-M }\end{array}$ & $40-50$ & 8 & $\begin{array}{l}{ }^{*} \text { 扬麦 } 13 \text { Yangmai 13, 镇麦 } 12 \text { Zhenmai 12, 华麦 } 6 \text { 号 Huamai 6, 安 } \\
\text { 农 } 1124 \text { Annong } 1124 \text {, 苏麦 } 188 \text { Sumai 188, 镇麦 } 11 \text { Zhenmai 11, } \\
\text { 扬麦 } 20 \text { Yangmai 20, 扬麦 } 22 \text { Yangmai } 22\end{array}$ \\
\hline & & $\begin{array}{l}\text { 氮低效 } \\
\text { NUR-L }\end{array}$ & $\leq 40$ & 8 & 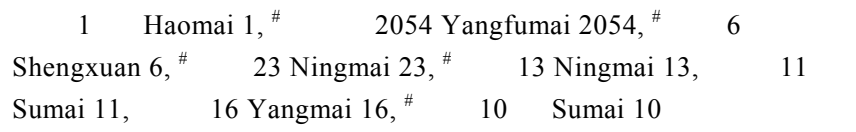 \\
\hline & & $\begin{array}{l}\text { 氮高效 } \\
\text { NUR-H }\end{array}$ & $\geq 50$ & 4 & $\begin{array}{l}\text { \#淮麦 } 35 \text { Huaimai 35, 瑞华 } 520 \text { Ruihua 520, 冠麦 } 1 \text { 号 Guanmai 1, } \\
\text { 江麦 } 919 \text { Jiangmai } 919\end{array}$ \\
\hline & $\begin{array}{l}\text { 睢宁 } \\
\text { Suining }\end{array}$ & $\begin{array}{l}\text { 氮中效 } \\
\text { NUR-M }\end{array}$ & $40-50$ & 13 & 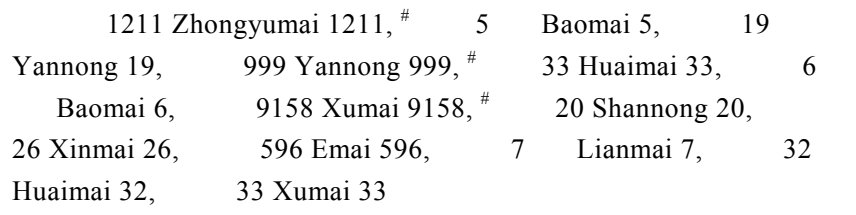 \\
\hline & & $\begin{array}{l}\text { 氮低效 } \\
\text { NUR-L }\end{array}$ & $\leq 40$ & 6 & $\begin{array}{l}\text { 明麦 } 1 \text { 号 Mingmai 1, 济麦 } 22 \text { Jimai 22, 保麦 } 2 \text { 号 Baomai 2, 鄂麦 } \\
580 \text { Emai 580, 郑麦 } 9023 \text { Zhengmai 9023, 安农 } 0711 \text { Annong } 0711\end{array}$ \\
\hline \multirow[t]{6}{*}{$2017-2018$} & $\begin{array}{l}\text { 扬州 } \\
\text { Yangzhou }\end{array}$ & $\begin{array}{l}\text { 氮高效 } \\
\text { NUR-H }\end{array}$ & $\geq 50$ & 2 & "扬麦 25 Yangmai 25, \#宁麦 21 Ningmai 21 \\
\hline & & $\begin{array}{l}\text { 氮中效 } \\
\text { NUR-M }\end{array}$ & $40-50$ & 6 & $\begin{array}{l}\text { 苏麦 } 11 \text { Sumai 11, 华麦 } 7 \text { 号 Huamai 7, 浩麦 } 1 \text { 号 Haomai 1, 扬麦 } \\
16 \text { Yangmai 16, }{ }^{*} \text { 扬麦 } 13 \text { Yangmai 13, 扬辐麦 } 1025 \text { Yangfumai } 1025\end{array}$ \\
\hline & & $\begin{array}{l}\text { 氮低效 } \\
\text { NUR-L }\end{array}$ & $\leq 40$ & 16 & 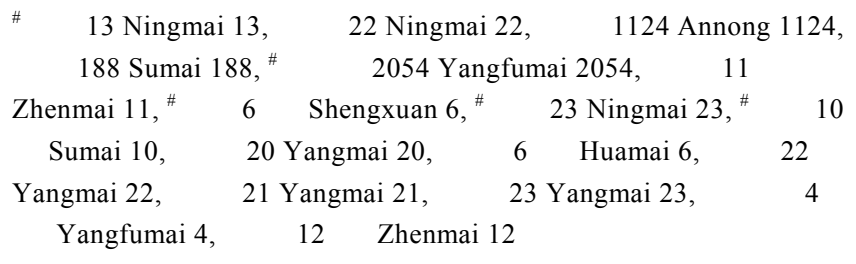 \\
\hline & $\begin{array}{l}\text { 睢宁 } \\
\text { Suining }\end{array}$ & $\begin{array}{l}\text { 氮高效 } \\
\text { NUR-H }\end{array}$ & $\geq 50$ & 2 & \#淮麦 35 Huaimai 35, 郑麦 9023 Zhengmai 9023 \\
\hline & & $\begin{array}{l}\text { 氮中效 } \\
\text { NUR-M }\end{array}$ & $40-50$ & 7 & $\begin{array}{l}\text { 安农 } 0711 \text { Annong } 0711 \text {, 徐麦 } 33 \text { Xumai 33, }{ }^{*} \text { 保麦 } 5 \text { 号 Baomai 5, 明 } \\
\text { 麦 } 1 \text { 号 Mingmai 1, 济麦 } 22 \text { Jimai 22, }{ }^{*} \text { 山农 } 20 \text { Shannong 20, }{ }^{*} \text { 淮麦 } \\
33 \text { Huaimai } 33\end{array}$ \\
\hline & & $\begin{array}{l}\text { 氮低效 } \\
\text { NUR-L }\end{array}$ & $\leq 40$ & 14 & $\begin{array}{l}\text { \#保麦 } 2 \text { 号 Baomai 2, 烟农 } 19 \text { Yannong 19, 徐麦 } 9158 \text { Xumai 9158, } \\
\text { 冠麦 } 1 \text { 号 Guanmai 1, 瑞华 } 520 \text { Ruihua 520, 江麦 } 919 \text { Jiangmai 919, } \\
\text { 淮麦 } 32 \text { Huaimai 32, 保麦 } 6 \text { 号 Baomai 6, 中育麦 } 1211 \text { Zhongyumai } \\
\text { 1211, 鄂麦 } 596 \text { Emai 596, \#鄂麦 } 580 \text { Emai 580, 烟农 } 999 \text { Yannong } \\
\text { 999, 新麦 } 26 \text { Xinmai 26, 连麦 } 7 \text { 号 Lianmai } 7\end{array}$ \\
\hline
\end{tabular}

\#: 两年度氮效率类型表现一致的品种。参试品种顺序按氮肥表观利用率由高到低排列。

NUR-H: nitrogen utilization rate with high-efficiency; NUR-M: nitrogen utilization rate with middle-efficiency; NUR-L: nitrogen utilization rate with low-efficiency. ": The cultivars have the same NUR in the two years. The tested varieties were ranked from high to low according to NUR. 
表 2 不同氮效率品种类型间产量及其构成因素的差异

Table 2 Differences in yield and its components among different NUR groups

\begin{tabular}{|c|c|c|c|c|c|c|c|}
\hline $\begin{array}{l}\text { 年份 } \\
\text { Year }\end{array}$ & $\begin{array}{l}\text { 地点 } \\
\text { Site }\end{array}$ & $\begin{array}{l}\text { 品种类型 } \\
\text { Variety type }\end{array}$ & $\begin{array}{c}\text { 氮肥表观利用率 } \\
\text { NUR (\%) }\end{array}$ & $\begin{array}{c}\text { 籽粒产量 } \\
\text { Grain yield } \\
\left(\mathrm{kg} \mathrm{hm}^{-2}\right) \\
\end{array}$ & $\begin{array}{c}\text { 穗数 } \\
\text { Spike number } \\
\left(\times 10^{4} \mathrm{hm}^{-2}\right)\end{array}$ & $\begin{array}{c}\text { 每穗粒数 } \\
\text { Grains per spike }\end{array}$ & $\begin{array}{c}\text { 千粒重 } \\
\text { 1000-grain } \\
\text { weight (g) }\end{array}$ \\
\hline \multirow[t]{10}{*}{ 2016-2017 } & 扬州 & 氮高效 NUR-H & $52.4 \pm 1.9 \mathrm{a}$ & $7439 \pm 321 \mathrm{a}$ & $362 \pm 23$ a & $44.8 \pm 5.2 \mathrm{a}$ & $48.6 \pm 4.3 \mathrm{a}$ \\
\hline & Yangzhou & 氮中效 NUR-M & $43.2 \pm 1.7 \mathrm{~b}$ & $6530 \pm 425 \mathrm{~b}$ & $330 \pm 29$ a & $43.7 \pm 6.1 \mathrm{a}$ & $47.4 \pm 4.5 \mathrm{a}$ \\
\hline & & 氮低效 NUR-L & $34.9 \pm 2.3 \mathrm{c}$ & $5410 \pm 662 \mathrm{c}$ & $294 \pm 25$ b & $42.3 \pm 4.2 \mathrm{a}$ & $45.7 \pm 3.6 \mathrm{a}$ \\
\hline & & 范围 Range & $31.4-55.8$ & $4158-7949$ & $253-400$ & $38.2-50.3$ & $41.1-57.3$ \\
\hline & & 平均值 Mean & 43.55 & 6470 & 331 & 43.0 & 47.3 \\
\hline & 睢宁 & 氮高效 NUR-H & $52.4 \pm 1.4 \mathrm{a}$ & $9064 \pm 230 \mathrm{a}$ & $513 \pm 40 \mathrm{a}$ & $40.0 \pm 1.8 \mathrm{a}$ & $46.6 \pm 2.6 \mathrm{a}$ \\
\hline & Suining & 氮中效 NUR-M & $46.2 \pm 2.4 \mathrm{~b}$ & $8564 \pm 425 \mathrm{a}$ & $500 \pm 36 \mathrm{ab}$ & $40.1 \pm 4.3 \mathrm{a}$ & $45.2 \pm 1.9 \mathrm{a}$ \\
\hline & & 氮低效 NUR-L & $36.6 \pm 2.1 \mathrm{c}$ & $7084 \pm 767 \mathrm{~b}$ & $434 \pm 53 \mathrm{~b}$ & $37.4 \pm 3.3 \mathrm{a}$ & $47.1 \pm 2.1 \mathrm{a}$ \\
\hline & & 范围 Range & $33.5-53.5$ & $6186-9370$ & $373-563$ & $33.1-48.8$ & $41.6-50.5$ \\
\hline & & 平均值 Mean & 44.44 & 8252 & 485 & 39.4 & 46.0 \\
\hline \multirow[t]{10}{*}{ 2017-2018 } & 扬州 & 氮高效 NUR-H & $50.8 \pm 0.7 \mathrm{a}$ & $6964 \pm 578$ a & $433 \pm 29$ a & $41.6 \pm 0.9 \mathrm{a}$ & $39.9 \pm 1.7 \mathrm{a}$ \\
\hline & Yangzhou & 氮中效 NUR-M & $42.8 \pm 2.2 \mathrm{~b}$ & $6397 \pm 462 \mathrm{ab}$ & $402 \pm 20 \mathrm{ab}$ & $43.5 \pm 3.3 \mathrm{a}$ & $39.2 \pm 3.1 \mathrm{a}$ \\
\hline & & 氮低效 NUR-L & $37.1 \pm 2.3 \mathrm{c}$ & $5806 \pm 478 \mathrm{~b}$ & $383 \pm 24 b$ & $42.6 \pm 3.2 \mathrm{a}$ & $38.0 \pm 2.7 \mathrm{a}$ \\
\hline & & 范围 Range & $38.9-53.6$ & $4878-7373$ & $324-454$ & $36-47.5$ & $34.2-44.4$ \\
\hline & & 平均值 Mean & 39.7 & 6070 & 393 & 42.8 & 38.5 \\
\hline & 睢宁 & 氮高效 NUR-H & $51.3 \pm 0.8 \mathrm{a}$ & $7097 \pm 101 \mathrm{a}$ & $505 \pm 2.8 \mathrm{a}$ & $37.6 \pm 0.7 \mathrm{a}$ & $41.3 \pm 0.6 \mathrm{a}$ \\
\hline & Suining & 氮中效 NUR-M & $41.7 \pm 1.6 \mathrm{~b}$ & $7114 \pm 373 \mathrm{a}$ & $495 \pm 25 \mathrm{a}$ & $36.6 \pm 3.7 \mathrm{a}$ & $42.0 \pm 3.5 \mathrm{a}$ \\
\hline & & 氮低效 NUR-L & $31.9 \pm 4.1 \mathrm{c}$ & $6249 \pm 473 \mathrm{~b}$ & $444 \pm 38 \mathrm{~b}$ & $36.9 \pm 1.5 \mathrm{a}$ & $39.7 \pm 3.2$ a. \\
\hline & & 范围 Range & $5237-7860$ & $33.5-53.5$ & $394-545$ & $32.8-43.9$ & $35.4-46.5$ \\
\hline & & 平均值 Mean & 6533 & 36.27 & 463 & 37.0 & 40.8 \\
\hline
\end{tabular}

数字后不同字母表示不同品种类型间差异达 0.05 显著水平。缩写同表 1 。

Values within a column followed by different letters are significantly different among different NUR groups at $P<0.05$. Abbreviations are the same as those given in Table 1.

$4878 \sim 7373 \mathrm{~kg} \mathrm{hm}^{-2}$, 平均为 $6070 \mathrm{~kg} \mathrm{hm}^{-2}$; 氮肥表观 利用率变幅为 $38.9 \% \sim 53.6 \%$, 平均为 $39.7 \%$ 。㫿宁参 试的小麦品种籽粒产量变幅为 $5237 \sim 7860 \mathrm{~kg} \mathrm{hm}$, 平均为 $6533 \mathrm{~kg} \mathrm{hm}^{-2}$; 氮肥表观利用率变幅为 $33.5 \% \sim 53.5 \%$, 平均为 $36.27 \%$ 。

\section{2 不同氮效率品种的产量及其构成因素}

由表 2 可以看出，氮高效品种籽粒产量均高于 氮中效和氮低效品种。扬州和睢宁参试的氮高效品 种产量较氮中效品种分别高 16\%、9\% (2017)和 13\%、
$1 \%$ (2018), 较氮低效品种分别高 37\%、25\% (2017) 和 $21 \% 、 15 \%$ (2018)。从产量构成因素来看, 氮高效 品种的穗数与氮中效品种差异均不显著, 但显著高 于氮低效品种，两年度在扬州分别高 $23 \%$ 和 $21 \%$ 、在 睢宁分别高 $15 \%$ 和 $17 \%$ 。两地不同品种类型间穗粒数 和千粒重差异均未达显著水平。相关性分析表明, 两 年度扬州和睢宁参试品种的产量、穗数与氮肥表观利 用率均呈显著线性正相关(图 1 和图 2 )。综上, 氮肥 表观利用率高的品种产量高, 且具有穗数高的特征。 

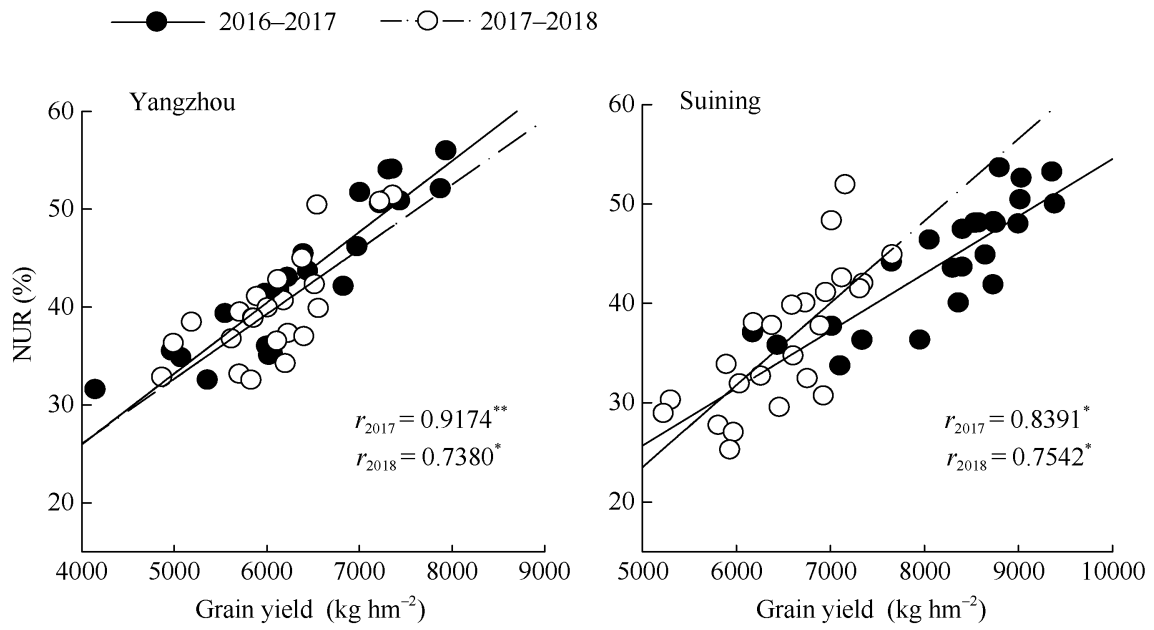

图 2 不同小麦品种产量与氮肥表观利用率的关系

Fig. 2 Relationships between grain yield and NUR in different wheat cultivars

*、**分别表示品种类型间差异显著 $(P<0.05)$ 和差异极显著 $(P<0.01)$ 。

${ }^{*}$ and ${ }^{* *}$ indicate a significant difference between types of cultivars at $P<0.05$ and $P<0.01$, respectively.

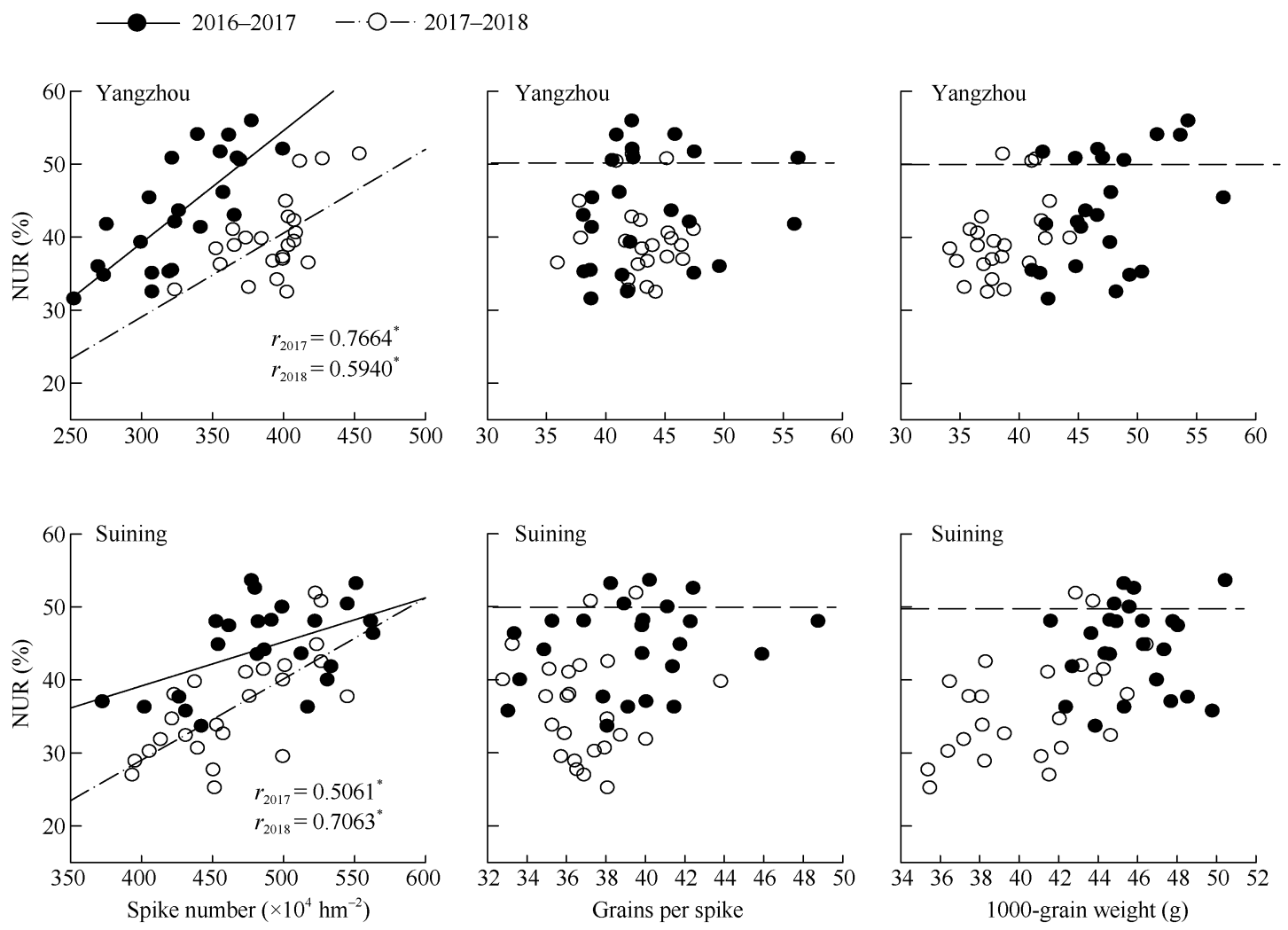

图 3 不同小麦品种产量构成因素与氮肥表观利用率关系

Fig. 3 Relationships of NUR with each yield components in different wheat cultivars

"表示品种类型间差异显著 $(P<0.05)$ 。

* indicates a significant difference between types of cultivars at $P<0.05$.

\section{3 不同氮效率品种的茎毟数和分蓝成穗率}

由图 4 可知, 不同氮效率品种类型间拔节期、 孕穗期、开花期和成熟期茎藮数均存在差异, 总体 表现为氮高效品种 $>$ 氮中效品种>氮低效品种。除
两地 2017 年度拔节期茎藮数在不同品种类型间差 异不显著外, 氮高效品种各主要生育时期茎藮数 均高于氮中效品种，显著高于氮低效品种。相关性 分析表明, 除 2017 年度拔节期茎菜数与氮肥表观 
利用率无显著相关性外，两年度两地拔节期、孕穗 期和开花期茎菜数与氮肥表观利用率均呈显著线 性正相关(表 3)。根据图 5 可知, 分蓝成穗率在不 同品种类型间表现为氮高效品种 $>$ 氮中效品种 $>$ 氮 低效品种, 仅 2017 年度扬州和 2018 年度睢宁参试 的氮高效品种分藍成穗率显著高于氮低效品种。 说明氮肥表观利用率高的品种具有分菜能力强的 特征。

\section{4 不同氮效率品种的叶面积指数}

由图 6 可知, 各主要生育时期 LAI 均表现为氮 高效品种>氮中效品种>氮低效品种。除 2017 年度两 地拔节期 LAI 和睢宁孕穗期 LAI 在氮高效品种与氮 低效品种间差异未达到显著水平外, 其余主要生育 时期 LAI 均表现为氮高效品种显著高于氮低效品种,
但与氮中效品种差异不显著。相关性分析表明, 两 年度扬州参试品种开花期和乳熟期 LAI 与氮肥表观 利用率均呈显著线性正相关，睢宁参试品种乳熟期 LAI 与氮肥表观利用率呈显著线性正相关(表 3)。说 明氮肥表观利用率高的品种在生育中后期具有较高 的绿叶面积。

\section{5 不同氮效率品种的干物质积累和转运}

两年度扬州和睢宁孕穗期、开花期和成熟期干 物质积累量表现为氮高效品种 $>$ 氮中效品种 $>$ 氮低效 品种。两年度两地氮高效品种各主要生育时期干物 质积累量均显著高于氮低效品种(表 4)。相关性分析 表明，两年度扬州和睢宁参试品种孕穗期、开花期 和成熟期干物质积累量与氮肥表观利用率均呈显著 线性正相关(表 3)。
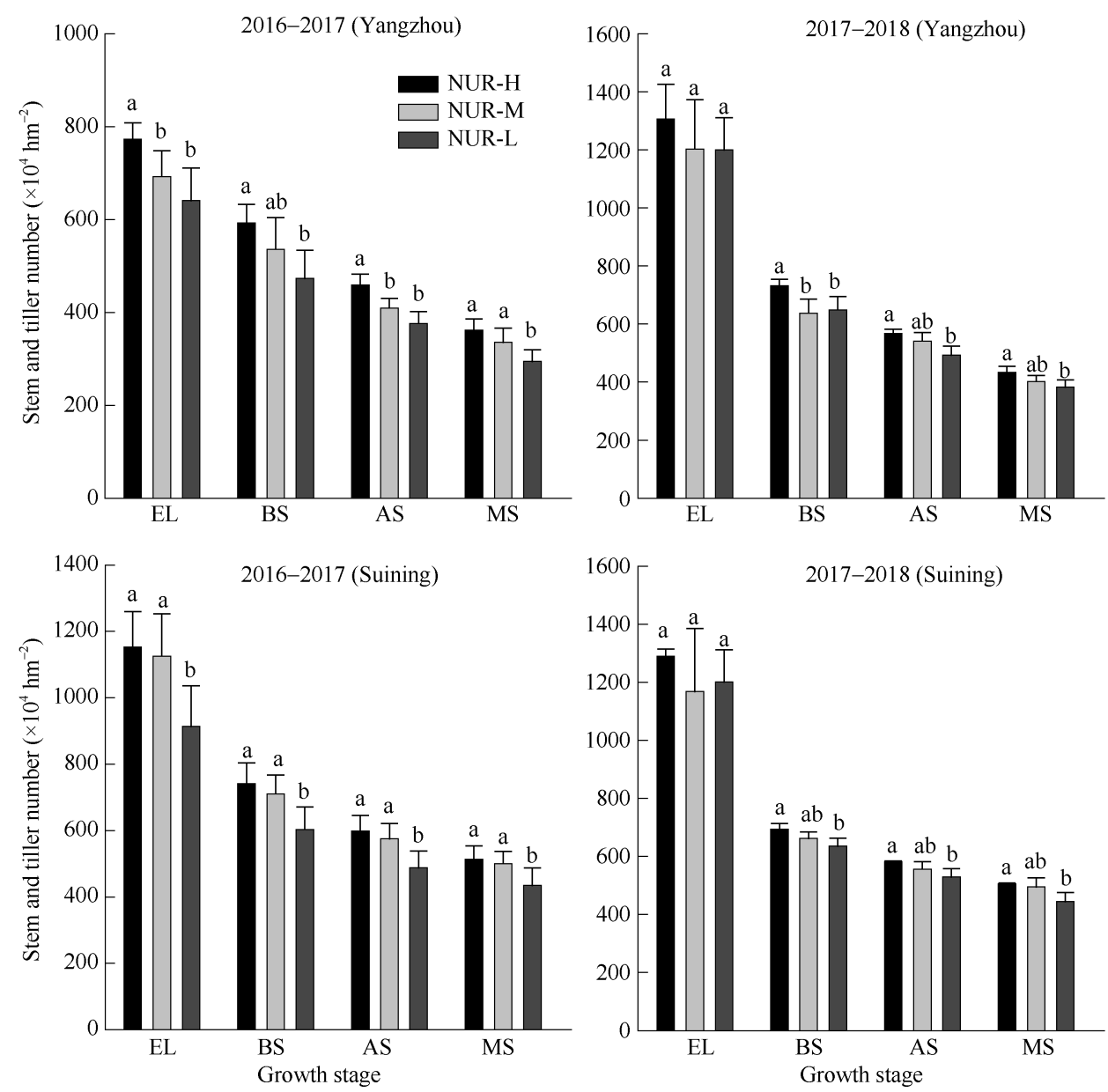

图 4 不同氮效率品种类型间主要生育期茎竪数差异

Fig. 4 Differences in the stem and tiller number at different stages among different NUR cultivars 图中不同小写字母表示不同氮效率品种类型间差异达 0.05 显著水平。AS: 开花期; 其他缩写同图 1 和表 1 。

Bars labelled with different letters are significantly different among different NUR groups at $P<0.05$. AS: anthesis stage; Other abbreviations are the same as those given in Fig. 1 and Table 1. 

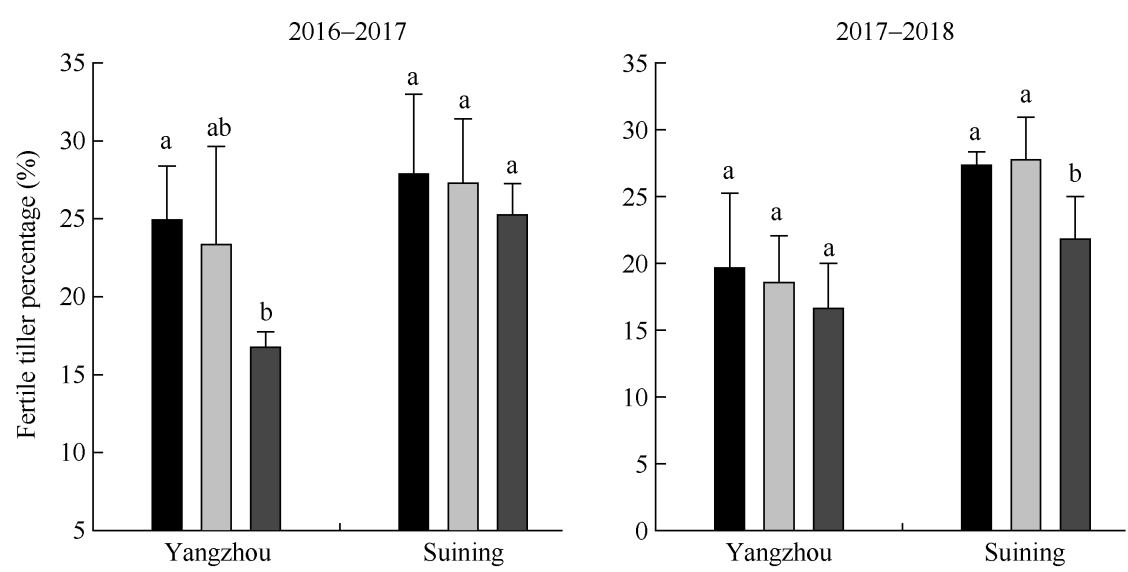

图 5 不同氮效率品种类型间分藍成穗率的差异

Fig. 5 Differences in fertile tiller percentage among different NUR cultivars

图中不同小写字母表示不同氮效率品种类型间差异达 0.05 显著水平。

Bars labelled with different letters are significantly different among different NUR groups at $P<0.05$.

\section{表 3 不同小麦品种间氮肥表观利用率与群体质量关键指标的相关性分析}

Table 3 Correlation analysis between NUR and the parameters of population quality in different wheat cultivars

\begin{tabular}{|c|c|c|c|c|c|}
\hline \multirow{2}{*}{$\begin{array}{c}\text { 生长时期 } \\
\text { Growth stage }\end{array}$} & \multirow{2}{*}{$\begin{array}{c}\text { 指标 } \\
\text { Parameter }\end{array}$} & \multicolumn{2}{|c|}{$2016-2017$} & \multicolumn{2}{|c|}{$2017-2018$} \\
\hline & & $\begin{array}{c}\text { 扬州 } \\
\text { Yangzhou }\end{array}$ & $\begin{array}{c}\text { 睢宁 } \\
\text { Suining } \\
\end{array}$ & $\begin{array}{c}\text { 扬州 } \\
\text { Yangzhou }\end{array}$ & $\begin{array}{c}\text { 睢宁 } \\
\text { Suining }\end{array}$ \\
\hline 拔节期 EL & 茎藍数 Stem and tiller number $\left(\times 10^{4} \mathrm{hm}^{-2}\right)$ & $0.781^{*}$ & $0.605^{*}$ & 0.166 & 0.223 \\
\hline \multirow[t]{3}{*}{ 孕穗期 BS } & 叶面积指数 LAI & $0.765^{*}$ & $0.803^{*}$ & 0.350 & 0.353 \\
\hline & 干物质积累量 $\mathrm{DMA}\left(\mathrm{kg} \mathrm{hm}^{-2}\right)$ & $0.862^{* *}$ & $0.701^{*}$ & $0.632^{*}$ & $0.609^{*}$ \\
\hline & 茎藍数 Stem and tiller number $\left(\times 10^{4} \mathrm{hm}^{-2}\right)$ & $0.779^{*}$ & $0.625^{*}$ & $0.799^{*}$ & $0.637^{*}$ \\
\hline \multirow[t]{3}{*}{ 开花期 AS } & 叶面积指数 LAI & $0.749^{*}$ & $0.886^{* *}$ & $0.568^{*}$ & 0.171 \\
\hline & 干物质积累量 DMA $\left(\mathrm{kg} \mathrm{hm}^{-2}\right)$ & $0.903^{* *}$ & $0.717^{*}$ & $0.697^{*}$ & $0.801^{*}$ \\
\hline & 茎藮数 Stem and tiller number $\left(\times 10^{4} \mathrm{hm}^{-2}\right)$ & $0.760^{*}$ & $0.619^{*}$ & $0.637^{*}$ & $0.708^{*}$ \\
\hline 乳熟期 MR & 叶面积指数 LAI & $0.554^{*}$ & $0.800^{*}$ & $0.536^{*}$ & $0.684^{*}$ \\
\hline \multirow[t]{4}{*}{ 成熟期 MS } & 干物质积累量 DMA $\left(\mathrm{kg} \mathrm{hm}^{-2}\right)$ & $0.916^{* *}$ & $0.802^{*}$ & $0.727^{*}$ & $0.785^{*}$ \\
\hline & 茎秆+叶鞘干物质积累量 DMA in stem and leaf sheath $\left(\mathrm{kg} \mathrm{hm}^{-2}\right)$ & $0.746^{*}$ & $0.497^{*}$ & $0.753^{*}$ & $0.546^{*}$ \\
\hline & 叶片干物质积累量 DMA in leaf blade $\left(\mathrm{kg} \mathrm{hm}^{-2}\right)$ & $0.834^{*}$ & $0.610^{*}$ & $0.572^{*}$ & $0.739^{*}$ \\
\hline & 顷壳+穗轴干物质积累量 DMA in rachis and glumes $\left(\mathrm{kg} \mathrm{hm}^{-2}\right)$ & $0.842^{*}$ & $0.610^{*}$ & 0.303 & $0.575^{*}$ \\
\hline \multicolumn{2}{|c|}{ 花后干物质积累量 Post-anthesis dry matter $\left(\mathrm{kg} \mathrm{hm}^{-2}\right)$} & $0.708^{*}$ & $0.743^{*}$ & $0.739^{*}$ & $0.858^{*}$ \\
\hline \multicolumn{2}{|c|}{ 干物质转运量 Dry matter remobilization $\left(\mathrm{kg} \mathrm{hm}^{-2}\right)$} & 0.223 & 0.475 & $0.529^{*}$ & 0.317 \\
\hline \multicolumn{2}{|c|}{ 收获指数 Harvest index } & -0.145 & 0.222 & 0.156 & -0.093 \\
\hline
\end{tabular}

*和"*分别表示相关性显著 $(P<0.05)$ 和极显著 $(P<0.01)$ 。

EL: elongation; BT: booting stage; AS: anthesis stage; MR: milk-ripe stage; MS: maturity stage; DMA: dry matter accumulation. ${ }^{*}$ and ${ }^{* *}$ indicate significant correlation at the 0.05 and 0.01 probability levels, respectively.

由表 5 可知, 两年度两地花后干物质积累量表 现为氮高效品种>氮中效品种>氮低效品种，两地氮 高效品种花后干物质积累量均显著高于氮低效品 种。年度间两地不同氮效率品种类型间花前干物质
转运量和收获指数差异均未达到显著水平。相关性 分析表明, 扬州和睢宁参试品种花后干物质积累量 与氮肥表观利用率均呈显著线性正相关(表 3)。说明 氮肥表观利用率高的品种具有较强的干物质生产和 

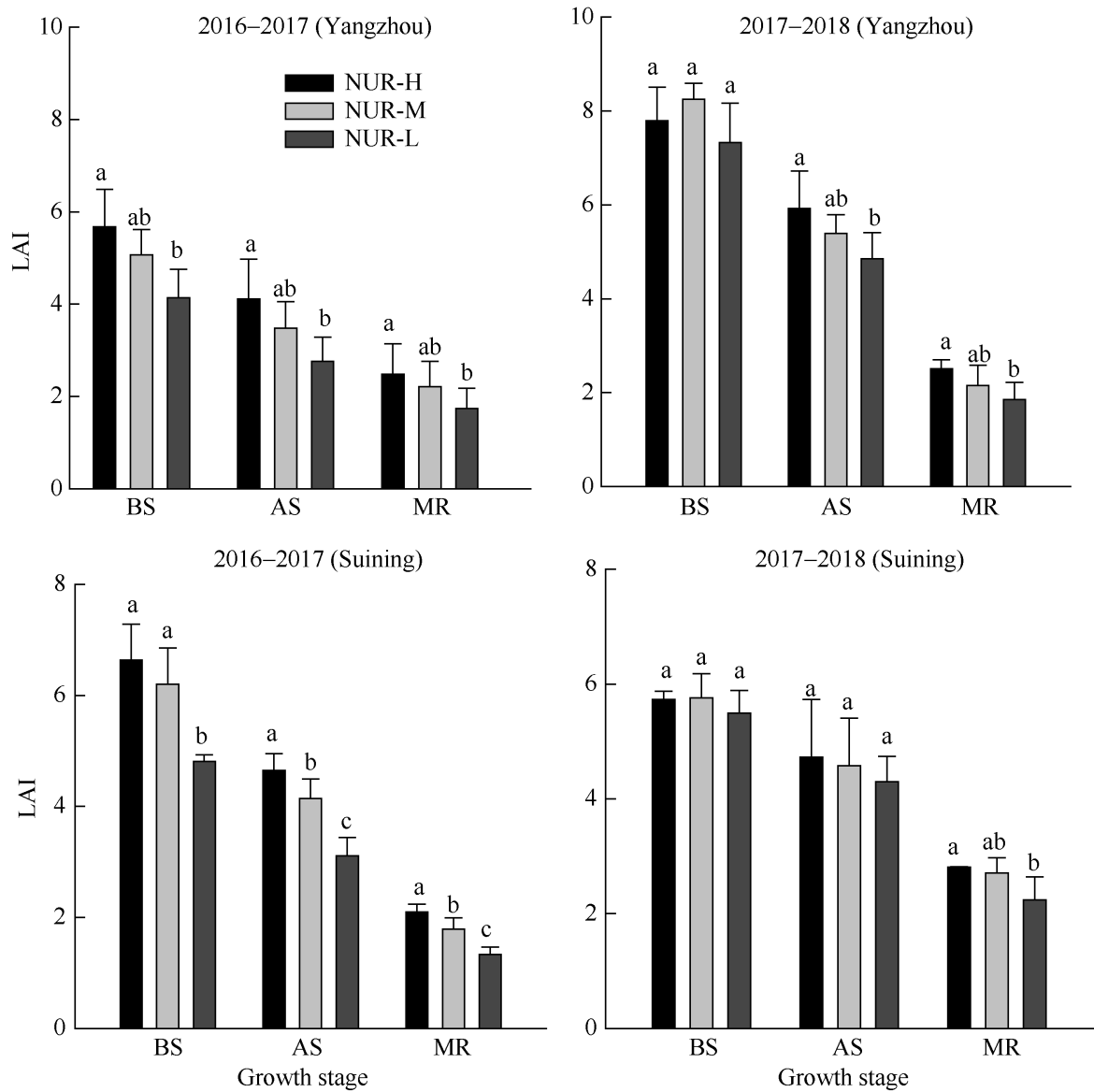

图 6 不同氮效率品种类型间主要生育时期 LAI 的差异

Fig. 6 Differences in LAI at each stage among different NUR cultivars

图中不同字母表示不同氮效率品种类型间差异达 0.05 显著水平。缩写同图 1 、表 1 和图 4 。

Bars labelled with different letters are significantly different among different NUR groups at $P<0.05$. Abbreviations are the same as those given in Fig. 1, Table 1, and Fig. 4.

\section{表 4 不同氮效率品种类型间主要生育时期干物质积累量的差异}

Table 4 Differences in dry matter accumulation at main stages among different NUR groups

\begin{tabular}{|c|c|c|c|c|c|}
\hline \multirow{2}{*}{$\begin{array}{l}\text { 年度 } \\
\text { Year }\end{array}$} & \multirow{2}{*}{$\begin{array}{l}\text { 地点 } \\
\text { Site }\end{array}$} & \multirow{2}{*}{$\begin{array}{c}\text { 品种类型 } \\
\text { Variety type }\end{array}$} & \multicolumn{3}{|c|}{ 干物质积累量 Dry matter accumulation $\left(\mathrm{kg} \mathrm{hm}^{-2}\right)$} \\
\hline & & & 孕穗期 Booting & 开花期 Anthesis & 成熟期 Maturity \\
\hline \multirow[t]{6}{*}{ 2016-2017 } & 扬州 & 氮高效 NUR-H & $6253 \pm 430$ a & $12728 \pm 289 \mathrm{a}$ & $18664 \pm 617 \mathrm{a}$ \\
\hline & Yangzhou & 氮中效 NUR-M & $4741 \pm 566 \mathrm{~b}$ & $11041 \pm 853 \mathrm{~b}$ & $16121 \pm 1566 \mathrm{~b}$ \\
\hline & & 氮低效 NUR-L & $4183 \pm 636 \mathrm{~b}$ & $9284 \pm 1028 \mathrm{c}$ & $13301 \pm 1360 \mathrm{c}$ \\
\hline & 睢宁 & 氮高效 NUR-H & $8958 \pm 418$ a & $13037 \pm 1015 \mathrm{a}$ & $18954 \pm 1087 \mathrm{a}$ \\
\hline & Suining & 氮中效 NUR-M & $8547 \pm 582 \mathrm{a}$ & $11683 \pm 1092 \mathrm{a}$ & $17505 \pm 1293 \mathrm{a}$ \\
\hline & & 氮低效 NUR-L & $7488 \pm 478 \mathrm{~b}$ & $10104 \pm 868 \mathrm{~b}$ & $14859 \pm 1201 \mathrm{~b}$ \\
\hline \multirow[t]{6}{*}{ 2017-2018 } & 扬州 & 氮高效 NUR-H & $9134 \pm 328$ a & $12372 \pm 664 \mathrm{a}$ & $16498 \pm 790 \mathrm{a}$ \\
\hline & Yangzhou & 氮中效 NUR-M & $8655 \pm 278 \mathrm{ab}$ & $11279 \pm 861 \mathrm{ab}$ & $14981 \pm 693 b$ \\
\hline & & 氮低效 NUR-L & $8099 \pm 494 \mathrm{~b}$ & $10335 \pm 810 \mathrm{~b}$ & $13794 \pm 941 \mathrm{~b}$ \\
\hline & 睢宁 & 氮高效 NUR-H & $7984 \pm 526$ a & $11704 \pm 604 \mathrm{a}$ & $16342 \pm 332 \mathrm{a}$ \\
\hline & Suining & 氮中效 NUR-M & $7235 \pm 752 \mathrm{ab}$ & $10295 \pm 966 \mathrm{~b}$ & $14581 \pm 1147 \mathrm{~b}$ \\
\hline & & 氮低效 NUR-L & $6625 \pm 744 \mathrm{~b}$ & $9195 \pm 976 \mathrm{~b}$ & $13260 \pm 1425 \mathrm{~b}$ \\
\hline
\end{tabular}

数字后不同字母表示不同氮效率品种类型间差异达 0.05 显著水平。

Values within a column followed by different letters are significantly different among different NUR groups at $P<0.05$. 
积累能力。进一步分析表明, 两年度扬州和睢宁参 试品种成熟期和花后干物质积累量与氮肥表观利用 率均呈显著线性正相关(图 7)。氮肥表观利用率达
$50 \%$ 以上的小麦品种成熟期和花后干物质积累量分 别在 16,000 20,000 kg hm${ }^{-2}$ 和 4100 6700 kg hm${ }^{-2}$, 可作为篮选高产高效品种的指标。

表 5 不同氮效率品种类型间干物质转运量、花后干物质积累量和收获指数的差异

Table 5 Differences in dry matter remobilization, post-anthesis dry matter accumulation and harvest index among different NUR groups

\begin{tabular}{|c|c|c|c|c|c|}
\hline $\begin{array}{l}\text { 年度 } \\
\text { Year }\end{array}$ & $\begin{array}{l}\text { 地点 } \\
\text { Site }\end{array}$ & $\begin{array}{c}\text { 品种类型 } \\
\text { Variety type }\end{array}$ & $\begin{array}{c}\text { 干物质转运量 } \\
\text { Dry matter remobilization } \\
\left(\mathrm{kg} \mathrm{hm}^{-2}\right)\end{array}$ & $\begin{array}{c}\text { 花后干物质积累量 } \\
\text { Post-anthesis dry matter } \\
\text { accumulation }\left(\mathrm{kg} \mathrm{hm}^{-2}\right)\end{array}$ & $\begin{array}{c}\text { 收获指数 } \\
\text { Harvest index }\end{array}$ \\
\hline \multirow[t]{6}{*}{ 2016-2017 } & 扬州 & 氮高效 NUR-H & $1448 \pm 299$ a & $6038 \pm 539$ a & $0.35 \pm 0.01 \mathrm{a}$ \\
\hline & Yangzhou & 氮中效 NUR-M & $1660 \pm 220 \mathrm{a}$ & $4889 \pm 554 \mathrm{~b}$ & $0.36 \pm 0.02 \mathrm{a}$ \\
\hline & & 氮低效 NUR-L & $1369 \pm 366 \mathrm{a}$ & $4478 \pm 849 \mathrm{~b}$ & $0.35 \pm 0.01 \mathrm{a}$ \\
\hline & 睢宁 & 氮高效 NUR-H & $3147 \pm 213 \mathrm{a}$ & $5916 \pm 269$ a & $0.42 \pm 0.02 \mathrm{a}$ \\
\hline & Suining & 氮中效 NUR-M & $2743 \pm 539 \mathrm{a}$ & $5821 \pm 528 \mathrm{a}$ & $0.44 \pm 0.02 \mathrm{a}$ \\
\hline & & 氮低效 NUR-L & $2431 \pm 490$ a & $4778 \pm 496 \mathrm{~b}$ & $0.42 \pm 0.02 \mathrm{a}$ \\
\hline \multirow[t]{6}{*}{ 2017-2018 } & 扬州 & 氮高效 NUR-H & $2010 \pm 251 \mathrm{a}$ & $4126 \pm 155 \mathrm{a}$ & $0.37 \pm 0.01 \mathrm{a}$ \\
\hline & Yangzhou & 氮中效 NUR-M & $1719 \pm 360 \mathrm{a}$ & $3701 \pm 348 \mathrm{ab}$ & $0.36 \pm 0.01 \mathrm{a}$ \\
\hline & & 氮低效 NUR-L & $1604 \pm 437$ a & $3459 \pm 386 \mathrm{~b}$ & $0.37 \pm 0.02 \mathrm{a}$ \\
\hline & 睢宁 & 氮高效 NUR-H & $1768 \pm 290 \mathrm{a}$ & $4558 \pm 391 \mathrm{a}$ & $0.38 \pm 0.01 \mathrm{a}$ \\
\hline & Suining & 氮中效 NUR-M & $1464 \pm 370 \mathrm{a}$ & $4243 \pm 417 \mathrm{ab}$ & $0.39 \pm 0.01 \mathrm{a}$ \\
\hline & & 氮低效 NUR-L & $1260 \pm 184 \mathrm{a}$ & $3923 \pm 379 \mathrm{~b}$ & $0.39 \pm 0.01 \mathrm{a}$ \\
\hline
\end{tabular}

数字后不同字母表示不同氮效率品种类型间差异达 0.05 显著水平。缩写同表 1 。

Values within a column followed by different letters are significantly different among different NUR groups at $P<0.05$. Abbreviations are the same as those given in Table 1.
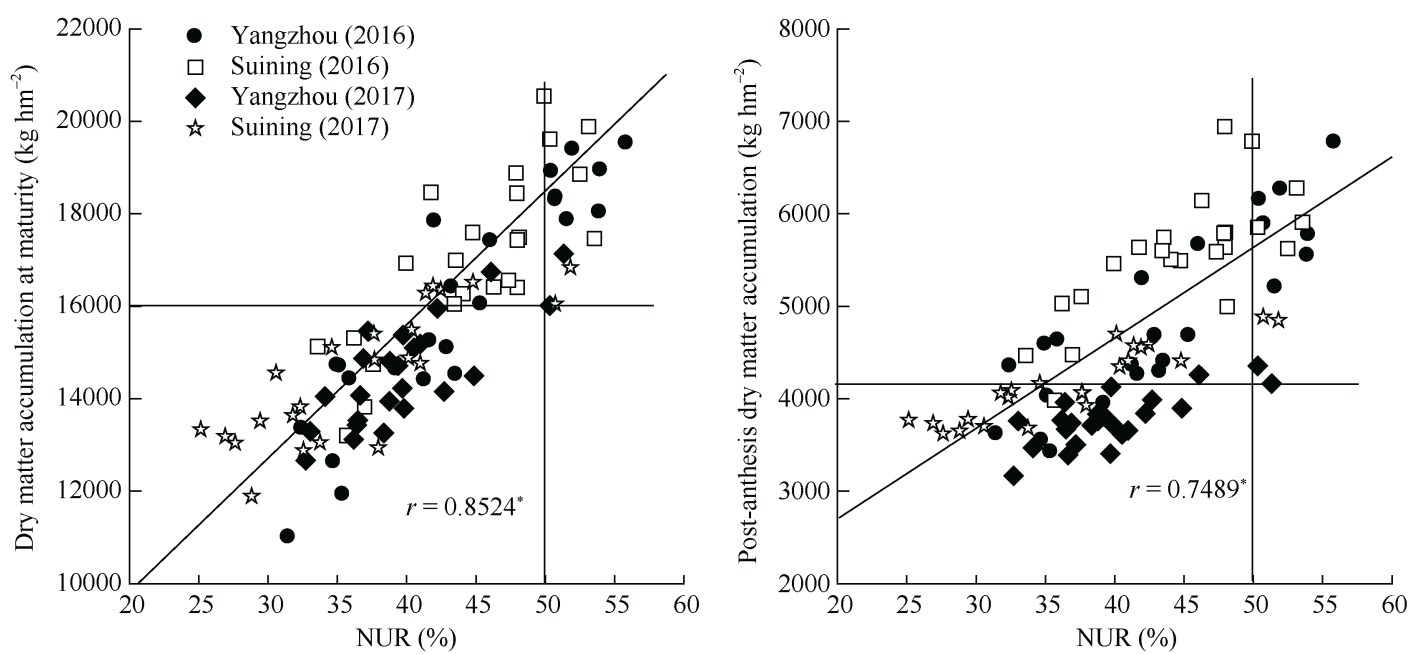

图 7 参试品种成熟期和花后干物质积累量与氮肥表观利用率的关系

Fig. 7 Relationships of dry matter accumulation at maturity and after anthesis with NUR in the tested cultivars

*表示相关性显著 $(P<0.05)$ 。

*indicate significant correlation at the 0.05 probability level.

\section{6 不同氮效率品种的营养器官干物质分配}

由表 6 可知, 成熟期茎秆+叶鞘、叶片、颖壳 + 穗轴的干物质积累量均表现为氮高效品种 $>$ 氮中效 品种>氮低效品种。除 2016 年度扬州参试品种间叶 片干物质积累量和 2017 年度㫿宁参试品种间颖壳 +
穗轴干物质积累量差异不显著外, 两地氮高效品种 各营养器官干物质积累量均显著高于氮低效品种。 相关性分析表明, 除 2016 年度扬州参试品种的叶片 干物质积累量和 2017 年度睢宁参试品种颖壳+穗轴 干物质积累量与氮肥表观利用率相关不显著外，两 
表 6 不同氮效率品种类型间成熟期营养器官干物质积累量的差异

Table 6 Differences in dry matter accumulation of vegetative organs at maturity among different NUR groups

\begin{tabular}{|c|c|c|c|c|c|}
\hline \multirow{2}{*}{$\begin{array}{l}\text { 年度 } \\
\text { Year }\end{array}$} & \multirow{2}{*}{$\begin{array}{l}\text { 地点 } \\
\text { Site }\end{array}$} & \multirow{2}{*}{$\begin{array}{c}\text { 品种类型 } \\
\text { Variety type }\end{array}$} & \multicolumn{3}{|c|}{ 干物质积累量 Dry matter accumulation $\left(\mathrm{kg} \mathrm{hm}^{-2}\right)$} \\
\hline & & & $\begin{array}{c}\text { 茎秆+叶鞘 } \\
\text { Stem and leaf sheath }\end{array}$ & $\begin{array}{c}\text { 叶片 } \\
\text { Leaf blade }\end{array}$ & $\begin{array}{c}\text { 穗轴十颖壳 } \\
\text { Rachis and glumes }\end{array}$ \\
\hline \multirow[t]{6}{*}{$2016-2017$} & 扬州 & 氮高效 NUR-H & $5421 \pm 276 \mathrm{a}$ & $1185 \pm 169 \mathrm{a}$ & $2268 \pm 234 \mathrm{a}$ \\
\hline & Yangzhou & 氮中效 NUR-M & $4598 \pm 520 \mathrm{~b}$ & $1051 \pm 169 \mathrm{ab}$ & $1980 \pm 302 \mathrm{ab}$ \\
\hline & & 氮低效 NUR-L & $4001 \pm 629 b$ & $895 \pm 176 b$ & $1742 \pm 281 \mathrm{~b}$ \\
\hline & 睢宁 & 氮高效 NUR-H & $5787 \pm 794$ a & $2296 \pm 453 \mathrm{a}$ & $2984 \pm 410$ a \\
\hline & Suining & 氮中效 NUR-M & $5262 \pm 518 \mathrm{ab}$ & $2086 \pm 411 \mathrm{a}$ & $2704 \pm 423 \mathrm{a}$ \\
\hline & & 氮低效 NUR-L & $4682 \pm 427 \mathrm{~b}$ & $1487 \pm 264 b$ & $2496 \pm 327$ a \\
\hline \multirow[t]{6}{*}{$2017-2018$} & 扬州 & 氮高效 NUR-H & $6405 \pm 275$ a & $1574 \pm 183$ a & $1770 \pm 217$ a \\
\hline & Yangzhou & 氮中效 NUR-M & $5872 \pm 708$ a & $1425 \pm 295$ a & $1722 \pm 527$ a \\
\hline & & 氮低效 NUR-L & $5679 \pm 592$ a & $1338 \pm 146$ a & $1374 \pm 243 b$ \\
\hline & 睢宁 & 氮高效 NUR-H & $6171 \pm 754 \mathrm{a}$ & $1612 \pm 183 \mathrm{a}$ & $1632 \pm 201 \mathrm{a}$ \\
\hline & Suining & 氮中效 NUR-M & $5615 \pm 716 \mathrm{ab}$ & $1528 \pm 237 \mathrm{ab}$ & $1571 \pm 190 \mathrm{ab}$ \\
\hline & & 氮低效 NUR-L & $4926 \pm 735 \mathrm{~b}$ & $1266 \pm 195 \mathrm{~b}$ & $1430 \pm 221 \mathrm{~b}$ \\
\hline
\end{tabular}

数字后不同字母表示不同氮效率品种类型间差异达 0.05 显著水平。缩写同表 1 。

Values within a column followed by different letters are significantly different among different NUR groups at $P<0.05$. Abbreviations are the same as those given in Table 1.

年度扬州和睢宁参试品种的成熟期各营养器官干物 质积累量与氮肥表观利用率均呈显著线性正相关 (表 3)。由此说明, 氮肥表观利用率高的品种成熟期 各营养器官干物质积累量均较高。

\section{3 讨论}

\section{1 稻茬小麦品种产量与氮效率的协同性分析}

目前，小麦产量的提高主要依赖于氮肥的大量 投入 ${ }^{[12]}$, 不同品种对氮肥的吸收和利用能力的差异, 造成不同品种全生育期内需氮量的差异。因此根据 不同品种对氮肥吸收和利用的特点, 选择合适的氮 肥施用量, 充分发挥不同品种的氮肥利用效率 ${ }^{[13]}$, 减少氮肥损失, 增加产量 ${ }^{[14]}$ 。有研究认为在一定范 围内随着施氮量的增加, 氮肥表观利用率高的品种 产量较高 ${ }^{[9,15]}$, 并且氮肥表观利用率高的品种增产 效果更加显著 ${ }^{[9]}$, 超过一定范围继续增施氮肥, 氮 高效品种产量增幅高于氮低效品种, 而氮高效品种 的氮肥表观利用率下降速率高于氮低效品种 ${ }^{[14]}$ 。亦 有研究表明, 在适播和晚播条件下, 氮高效品种的 产量均高于氮中效和氮低效品种 ${ }^{[9,12]}$ 。本试验条件下, 两年度扬州和㫿宁氮高效品种产量高于氮中效和氮 低效品种。表明, 通过節选氮肥表观利用率高的品 种, 有助于高产高效协同生产。

\section{2 稻茬小麦氮高效品种产量构成特征}

前人对不同氮效率小麦品种产量构成因素的研
究报道较多, 但结果不尽一致。李淑文等 ${ }^{[7]}$ 研究认为 旱茬小麦高氮肥表观利用率的品种具有较高的单位 面积穗数, 但穗粒数和千粒重在品种间差异不显 著。亦有研究表明旱茬小麦高氮肥表观利用率的 品种千粒重显著高于氮低效品种, 而穗粒数则相 反 ${ }^{[16]}$ 。而吴金芝等 ${ }^{[17]}$ 认为高氮肥表观利用率的小麦 品种具有较高的千粒重和稳定穗粒数。本试验结果 表明, 两地氮高效品种穗数均高于氮中效和氮低效 品种, 穗粒数和千粒重差异均不显著。表明在长江 中下游稻茬麦区可以通过相同种植密度条件下选择 穗数高的品种篮选出高氮肥表观利用率品种。

\section{3 稻茬小麦氮高效品种群体质量特征}

张旭等 ${ }^{[18]}$ 研究认为小麦氮肥表观利用率高的品 种孕穗期具有较高的 $\mathrm{LAI}$ 。李淑文等 ${ }^{[7]}$ 认为氮肥利用 效率高的品种各主要生育时期均具有较高的茎菜数 和 $\mathrm{LAI}_{\text {。丁口锦峰等 }}{ }^{[10]}$ 认为氮高效利用的小麦群体具 有较高的花后光合面积。本试验结果表明, 氮高效 品种孕穗期和开花期茎葟数和乳熟期 LAI 均高于氮 中效和氮低效品种。不同小麦品种间分藍成穗率存 在差异 ${ }^{[16]}$, 李淑文等 ${ }^{[7]}$ 研究表明氮高效品种分蒒成 穗率高于氮中效和氮低效品种。

不同氮效率小麦品种的干物质积累 ${ }^{[8]}$ 、分配和 运转能力 ${ }^{[19]}$ 存在显著差异。有研究表明小麦氮肥表 观利用率高的品种各主要生育时期干物质积累量均 
高于氮中效和氮低效品种 ${ }^{8}{ }^{[1}$, 并且氮肥表观利用 率高的群体具有更强的总的和花后干物质积累能 力 $^{[10]}$ 。不同氮肥表观利用率的水稻品种干物质积累 也有相似结果 ${ }^{[20]}$ 。本试验结果表明, 氮高效品种各 主要生育时期干物质积累量、花后和成熟期各器官 干物质积累量均高于氮中效和氮低效品种。说明稻 茬小麦氮高效品种生育前期具有较高的光合面积和 较强的分藍能力, 孕穗期后具有较强的光合物质生 产能力和较高的花后干物质积累能力。但不同试验 地点和年度间, 氮高效品种在上述指标上均存在较 大差异, 表明氮高效品种的篮选应在特定的生态区 开展, 且需要重复验证。

\section{4 稻茬小麦氮高效品种的篮选及其指标}

目前，对小麦氮高效品种的篮选指标不一。李淑 文等 ${ }^{[7]}$ 、徐晴等 ${ }^{[21]}$ 和吴金芝等 ${ }^{[17]}$ 研究不同小麦品种的 氮肥吸收与利用效率认为氮高效品种具有较高的氮 肥生理利用率、氮肥吸收利用效率或氮肥农学效率。 另有研究表明高氮肥表观利用率的小麦或水稻品种 具有较高的硝酸还原酶 ${ }^{[22]}$ 、谷氨酰胺合成酶 ${ }^{[23]}$ 、谷 氨酸合成酶 ${ }^{[24]}$ 活性。Fuentes 等 ${ }^{[23]}$ 和袁晓磊等 ${ }^{[25]}$ 研究 拟南芥和小麦氮代谢酶基因表达水平表明，较高的 谷氨酰胺合成酶基因、谷氨酸合成酶基因、丙氨酸转 氨酶基因和丙酮酸磷酸双激酶基因表达水平可以促 进作物对氮肥的吸收和利用。以上研究主要为探索不 同氮效率小麦品种对氮素吸收和利用差异的机制, 无法直观、快速地篮选出氮高效品种。亦有研究表明, 小麦氮高效品种具有较高的产量 ${ }^{[9,17]}$ 、茎藮数 ${ }^{[8]}$ 、 $\mathrm{LAI}^{[20]}$ 和干物质积累与转运量 ${ }^{[21]}$, 可作为篮选氮高效 小麦品种的依据。本研究结果表明, 不同小麦品种氮 肥表观利用率与产量、穗数、各主要生育时期茎藍数、 叶面积指数和干物质积累量、花后和成熟期各营养器 官的干物质积累量均呈极显著线性正相关。说明稻茬 条件下小麦氮高效品种的篮选可以综合利用产量、穗 数和各主要生育时期群体质量作为快速有效篮选依 据。虽然本文初步提出成熟期和花后干物质积累量 $16,000 \sim 20,000 \mathrm{~kg} \mathrm{hm}^{-2}$ 和 4100 6700 kg hm${ }^{-2}$ 可作为 稻茬小麦高产高效品种的篮选指标, 但相关参数还 有待进一步验证以提出关键篮选指标, 此外稻茬小 麦品种对氮素高效吸收与利用的形态、生理和分子机 制还有待明确。

\section{4 结论}

根据两年度品种的氮肥表观利用率，在扬州表 现高效的品种为扬麦 25 和宁麦 21 , 在㫿宁为淮麦
35。氮肥表观利用率高的品种也表现高产。高产高 效品种表现出生育前期较强的分藍能力, 生育后期 旺盛的物质生产能力, 尤其是花后有较多的光合物 质向籽粒转运。提出了稻茬小麦高产高效品种的篮选 指标为成熟期干物质积累量 $16,000 \sim 20,000 \mathrm{~kg} \mathrm{hm}^{-2}$ 和花后干物质积量 $4100 \sim 6700 \mathrm{~kg} \mathrm{hm}^{-2}$ 。

\section{References}

[1] Liu H, Wang Z H, Yu R, Li F C, Li K Y, Cao H B, Yang N, Li M H, Dai J, Zan Y L, Li Q, Xue C, He G, Huang D L, Huang M, Liu J S, Qiu W H, Zhao H B, Mao H. Optimal nitrogen input for higher efficiency and lower environmental impacts of winter wheat production in China. Agric Ecosyst Environ, 2016, 224: $1-11$.

[2] 王小纯, 王晓航, 熊淑萍, 马新明, 丁世杰, 吴克远, 郭建彪. 不同供氮水平下小麦品种的氮效率差异及其氮代谢特征. 中 国农业科学, 2015, 48: 2569-2579.

Wang X C, Wang X H, Xiong S P, Ma X M, Ding S J, Wu K Y, Guo J B. Differences in nitrogen efficiency and nitrogen metabolism of wheat varieties under different nitrogen. Sci Agric Sin, 2015, 48: 2569-2579 (in Chinese with English abstract).

[3] 张福锁, 王激清, 张卫峰, 崔振岭, 马文奇, 陈新平, 江荣风, 中国主要粮食作物肥料利用率现状与提高途径. 土壤学报, 2008, 45: 915-924.

Zhang F S, Wang J Q, Zhang W F, Cui Z L, Ma W Q, Chen X P, Jiang R F. Current status and improvement of fertilizer utilization rate of main grain crops in China. Acta Pedol Sin, 2008, 45: 915-924 (in Chinese with English abstract).

[4] 何文寿, 储燕宁, 王彦才, 杨发. 不同基因型小麦氮营养效率 的差异. 宁夏农学院学报, 1997, 18(4): 29-34.

He W S, Chu Y N, Wang Y C, Yang F. Differences in nitrogen nutrition efficiency between different genotypes of wheat. $J$ Ningxia Agric Coll, 1997, 18(4): 29-34 (in Chinese).

[5] 熊淑萍, 吴克远, 王小纯, 张捷, 杜盼, 吴懿金金, 马新明. 不同 氮效率基因型小麦根系吸收特性与氮素利用差异的分析. 中 国农业科学, 2016, 49: 2267-2279.

Xiong S P, Wu K Y, Wang X C, Zhang J, Du P, Wu Y X, Ma X M. Analysis of root absorption characteristics and nitrogen utilization of wheat genotypes with different N efficiency. Sci Agric Sin, 2016, 49: 2267-2279 (in Chinese with English abstract).

[6] 李继云, 刘秀娣, 周伟, 孙建华, 童依平, 刘文杰, 李振声, 王 培田, 姚树江. 有效利用土壤营养元素的作物育种新技术研 究. 中国科学(B 辑), 1995, 25: 41-48.

Li J Y, Liu X D, Zhou W, Sun J H, Tong Y P, Liu W J, Li Z S, Wang P T, Yao S J. Study on new techniques of crop breeding for effective utilization of soil nutrients. Sci China (Ser B), 1995, 25: 41-48 (in Chinese).

[7] 李淑文, 文宏达, 周彦珍, 李雁鸣, 肖凯. 不同氮效率小麦品 种氮素吸收和物质生产特性. 中国农业科学, 2006, 39: 1992-2000.

Li S W, Wen H D, Zhou Y Z, Li Y M, Xiao K. Characterization of nitrogen uptake and dry matter production in wheat varieties with different N efficiency. Sci Agric Sin, 2006, 39: 1992-2000 (in Chinese with English abstract). 
[8] 张洋, 张继, 强晓敏, 翟丙年, 王朝辉. 不同氮效率基因型冬 小麦生理特征的比较研究. 植物营养与肥料学报, 2010,16 : 1319-1324.

Zhang Y, Zhang J, Qiang X M, Zhai B N, Wang Z H. Comparative study on physiological characteristics in winter wheat with different nitrogen use efficiency. Plant Nutr Fert Sci, 2010, 16: 1319-1324 (in Chinese with English abstract).

[9] 韩胜芳, 李淑文, 吴立强, 文宏达, 肖凯. 不同小麦品种氮效 率与氮吸收对氮素供应的响应及生理机制. 应用生态学报, 2007, 18: 807-812.

Han S F, Li S W, Wu L Q, Wen H D, Xiao K. Responses and corresponding physiological mechanisms of different wheat varieties in their nitrogen. Chin J Appl Ecol, 2007, 18: 807-812 (in Chinese with English abstract).

[10] 丁锦峰, 成亚梅, 黄正金, 李春燕, 郭文善, 朱新开. 稻茬小 麦不同氮效率群体花后物质生产与衰老特性差异分析. 中国 农业科学, 2015, 48: 1063-1073.

Ding J F, Cheng Y M, Huang Z J, Li C Y, Guo W S, Zhu X K. Difference analysis of post-anthesis matter production and senescence characteristics among different nitrogen efficiency populations in wheat following rice. Sci Agric Sin, 2015, 48: 1063-1073 (in Chinese with English abstract).

[11] 吕伟仙, 葛漟, 吴建之, 常杰. 植物中硝态氮、氨态氮、总氮 测定方法的比较研究. 光谱学与光谱分析, 2004, 2: 204-206.

Lyu W X, Ge Y, Wu J Z, Chang J. Comparative study on determination methods of nitrate nitrogen, ammonia nitrogen and total nitrogen in plants. Spectroscopy Spectral Anal, 2004, 2: 204-206 (in Chinese).

[12] Zhang M M, Dong B D, Qiao Y Z, Shi C H, Yang H, Wang Y K, Liu M Y. Yield and water use responses of winter wheat to irrigation and nitrogen application in the North China plain. $J$ Integr Agric, 2018, 17: 1194-1206.

[13] 李朝苏, 吴晓丽, 汤永禄, 李俊, 马孝玲, 李式昭, 黄明波, 刘 沝. 小麦产量对中后期氮素胁迫的响应及品种间差异. 作物 学报, 2019, 45: 1260-1269.

Li C S, Wu X L, Tang Y L, Li J, Ma X L, Li S Z, Huang M B, Liu $M$. Response of yield and associated physiological characteristics for different wheat cultivars to nitrogen stress at mid-late growth stage. Acta Agron Sin, 2019, 45: 1260-1269 (in Chinese with English abstract).

[14] Lucie B, Raphaël C, David S, Sokrat S, Alexandra M, Dario F, Fabio M. Performance of eleven winter wheat varieties in a long term experiment on mineral nitrogen and organic fertilization. Field Crops Res, 2016, 191: 111-122.

[15] Dai X, Wang Y C, Dong X C, Qian T F, Yin L J, Dong S X, Chu J P, He M G. Delayed sowing can increase lodging resistance while maintaining grain yield and nitrogen use efficiency in winter wheat. Crop J, 2017, 5: 541-552.

[16] 魏艳丽, 王彬龙, 李瑞国, 蒋会利, 张平, 王磐, 张安静. 施氮 对不同小麦品种干物质分配、氮素吸收和产量的影响. 麦类作 物学报, 2012, 32: 1134-1138.

Wei Y L, Wang B L, Li R G, Jiang H L, Zhang P, Wang P, Zhang A J. Effects of nitrogen fertilizer application on distribution of dry material, assimilation of nitrogen and yield of different wheat varieties. J Triticeae Crops, 2012, 32: 1134-1138 (in Chinese with English abstract).

[17] 吴金芝, 黄明, 王志敏, 李友军, 付国占, 陈明灿. 极端晚播 对小麦籽粒产量、氮素吸收利用和籽粒蛋白质含量的影响. 应 用生态学报, 2018, 29: 185-192.

Wu J Z, Huang M, Wang Z M, Li Y J, Fu G Z, Chen M C. Effects of extremely-late sowing on the grain yield, nitrogen uptake and utilization and grain protein content in winter wheat. Chin J Appl Ecol, 2018, 29: 185-192 (in Chinese with English abstract).

[18] 张旭, 田中伟, 胡金玲, 修明, 姜东, 戴廷波. 小麦氮素高效 利用基因型的农艺性状及生理特性. 麦类作物学报, 2016, 36: 1315-1322.

Zhang X, Tian Z W, Hu J L, Xiu M, Jiang D, Dai T B. Agronomic and physiological characteristics of high efficient nitrogen utilization in wheat. $J$ Triticeae Crops, 2016, 36: 1315-1322 (in Chinese with English abstract).

[19] 李法计, 徐学欣, 肖永贵, 何中虎, 王志敏. 不同氮素处理对 中麦 175 和京冬 17 产量相关性状和氮素利用效率的影响. 作 物学报, 2016, 42: 1853-1863.

Li F J, Xu X X, Xiao Y G, He Z H, Wang Z M. Effect of nitrogen on yield related traits and nitrogen utilization efficiency in Zhongmai 175 and Jingdong 17. Acta Agron Sin, 2016, 42: 1853-1863 (in Chinese with English abstract).

[20] Pal R, Mahajan G, Sardana V, Chauhan B S. Impact of sowing date on yield, dry matter and nitrogen accumulation, and nitrogen translocation in dry-seeded rice in North-West India. Field Crops Res, 2017, 206: 138-148.

[21] 徐晴, 许甫超, 董静, 董建辉, 秦丹丹, 鲁梦藏, 李梅芳. 小麦 氮素利用效率的基因型差异及相关特性分析. 中国农业科学, 2017, 50: 2647-2657.

Xu Q, Xu F C, Dong J, Dong J H, Qin D D, Lu M Y, Li M F. Genotypic difference of nitrogen use efficiency of wheat and correlation analysis of the related characters. Sci Agric Sin, 2017, 50: 2647-2657 (in Chinese with English abstract).

[22] Tian Z W, Li Y, Liang Z H, Guo H, Cai J, Jiang D, Cao W X, Dai T B. Genetic improvement of nitrogen uptake and utilization of winter wheat in the Yangtze River Basin of China. Field Crops Res, 2016, 196: 251-260.

[23] Fuentes S I, Allen D J, Ortiz Lopez A, Hernández G. Over-expression of cytosolic glutamine synthetase increases photosynthesis and growth at low nitrogen concentrations. $J$ Exp Bot, 2001, 52: 1071-1081.

[24] 叶利庭, 吕华军, 宋文静, 图尔迪, 沈其荣, 张亚丽. 不同氮 效率水稻生育后期氮代谢酶活性的变化特征. 土壤学报, 2011, 48: 132-140.

Ye L T, Lyu H J, Song W J, Tu E D, Shen Q R, Zhang Y L. Changes of nitrogen metabolism enzyme activities in late growth stage of rice with different nitrogen efficiency. Acta Pedol Sin, 2011, 48: 132-140 (in Chinese).

[25] 袁晓磊, 田汇, 高亚军. 不同氮利用效率小麦氮代谢相关基因 的表达特征. 中国土壤与肥料, 2017, (1): 48-55.

Yuan X L, Tian H, Gao Y J. Seasonal expression of genes related to nitrogen metabolism in wheat with different nitrogen utilization efficiencies. China Soils Fert, 2017, (1): 48-55 (in Chinese with English abstract). 